\title{
ErbB2 Signaling in Schwann Cells Is Mostly Dispensable for Maintenance of Myelinated Peripheral Nerves and Proliferation of Adult Schwann Cells after Injury
}

\author{
Suzana Atanasoski, ${ }^{1}$ Steven S. Scherer, ${ }^{2}$ Erich Sirkowski, ${ }^{2}$ Dino Leone, ${ }^{1}$ Alistair N. Garratt, ${ }^{3}$ Carmen Birchmeier, ${ }^{3}$ and \\ Ueli Suter ${ }^{1}$ \\ ${ }^{1}$ Institute of Cell Biology, Department of Biology, ETH Zurich, CH-8093 Zurich, Switzerland, ${ }^{2}$ Department of Neurology, University of Pennsylvania School \\ of Medicine, Philadelphia, Pennsylvania 19104-6146, and ${ }^{3}$ Max-Delbrück-Centrum for Molecular Medicine, 13092 Berlin, Germany
}

\begin{abstract}
Neuregulin/erbB signaling is critically required for survival and proliferation of Schwann cells as well as for establishing correct myelin thickness of peripheral nerves during development. In this study, we investigated whether erbB2 signaling in Schwann cells is also essential for the maintenance of myelinated peripheral nerves and for Schwann cell proliferation and survival after nerve injury. To this end, we used inducible Cre-loxP technology using a PLP-CreERT2 allele to ablate erbB2 in adult Schwann cells. ErbB2 expression was markedly reduced after induction of $e r b B 2$ gene disruption with no apparent effect on the maintenance of already established myelinated peripheral nerves. In contrast to development, Schwann cell proliferation and survival were not impaired in mutant animals after nerve injury, despite reduced levels of MAPK-P (phosphorylated mitogen-activated protein kinase) and cyclin D1. ErbB1 and erbB4 do not compensate for the loss of erbB2. We conclude that adult Schwann cells do not require major neuregulin signaling through erbB2 for proliferation and survival after nerve injury, in contrast to development and in cell culture.
\end{abstract}

Key words: peripheral nerves; Schwann cells; Wallerian degeneration; receptor tyrosine kinases; Cre-loxP system; proliferation

\section{Introduction}

Lesions of peripheral nerves initiate a sequence of cellular changes distal to the injury known as Wallerian degeneration (Griffin and Hoffman, 1993; Scherer and Salzer, 2001). They include axonal degeneration, myelin breakdown, and dedifferentiation and proliferation of Schwann cells. The molecular phenotype of "denervated" Schwann cells in axotomized nerves is similar to immature Schwann cells in developing nerves (Jessen and Mirsky, 2005; Sherman and Brophy, 2005). However, control of proliferation differs. Schwann cell proliferation is independent of cyclin D1 in development, but injury-induced proliferation is strongly impaired in the absence of cyclin D1 (Kim et al., 2000; Atanasoski et al., 2001). Furthermore, the cell cycle inhibitor p21 regulates Schwann cell proliferation in development and after injury by different mechanisms (Atanasoski et al., 2006). Characterizing the molecular signals that control the response of Schwann cells to injury has implications for our understanding of disease mechanisms in inherited and acquired neu-

\footnotetext{
Received Aug. 7, 2005; revised Jan. 4, 2006; accepted Jan. 11, 2006.

This work was supported by grants from the Swiss National Science Foundation, the Swiss Foundation for Muscle Diseases, and the National Center of Competence in Research on Neural Plasticity and Repair. We thank Dr. Cary Lai for anti-erbB4 antibodies, Tina Thurnherr for protein extracts of cultured oligodendrocytes, and Katja Wichmann for excellent technical assistance.

Correspondence should be addressed to Dr. Ueli Suter, Institute of Cell Biology, ETH-Hönggerberg, CH-8093 Zurich, Switzerland. E-mail: usuter@cell.biol.ethz.ch.

D. Leone's present address: Department of Biological Sciences, Stanford University, Stanford, CA 94305-5020. DOI:10.1523/JNEUROSCI.4594-05.2006

Copyright $\odot 2006$ Society for Neuroscience $\quad 0270-6474 / 06 / 262124-08 \$ 15.00 / 0$
}

ropathies (Suter and Scherer, 2003; Berger and Schaumburg, 1995).

Schwann cells express erbB2 and erbB3 forming functional heterodimeric receptors for neuregulins (Cohen et al., 1992; Jin et al., 1993; Ho et al., 1995; Levi et al., 1995; Grinspan et al., 1996; Carroll et al., 1997; Vartanian et al., 1997). ErbB2 and erbB3 are obligate heterodimers, because erbB2 alone does not efficiently bind neuregulins and erbB3 has no kinase activity (Sliwkowski et al., 1994). In development, neuregulin-1 isoforms have potent effects on differentiation, survival, and proliferation of Schwann cells (Shah et al., 1994; Dong et al., 1995; Morrissey et al., 1995; Grinspan et al., 1996; Trachtenberg and Thompson, 1996). Animals deficient in erbB2, erbB3, or the PNS-enriched isoform of neuregulin-1, show reduced numbers of precursors and immature Schwann cells (Riethmacher et al., 1997; Britsch et al., 1998; Morris et al., 1999; Woldeyesus et al., 1999; Wolpowitz et al., 2000). Lowered expression of the neuronal neuregulin-1, or conditional ablation of erbB2 in late Schwann cell development, causes defects in postnatal Schwann cell differentiation and the formation of abnormally thin myelin sheaths (Garratt et al., 2000; Chan et al., 2004; Michailov et al., 2004; Taveggia et al., 2005). Conversely, overexpression of axonal neuregulin-1 in transgenic animals induces hypermyelination (Michailov et al., 2004).

We hypothesized that erbB2/erbB3 receptor signaling plays also an active role in proliferation control of adult Schwann cells after nerve injury. Schwann cell proliferation in Wallerian degeneration follows a predictable time course (Bradley and Asbury, 1970) and the expression of neuregulin and the tyrosine receptors 
A
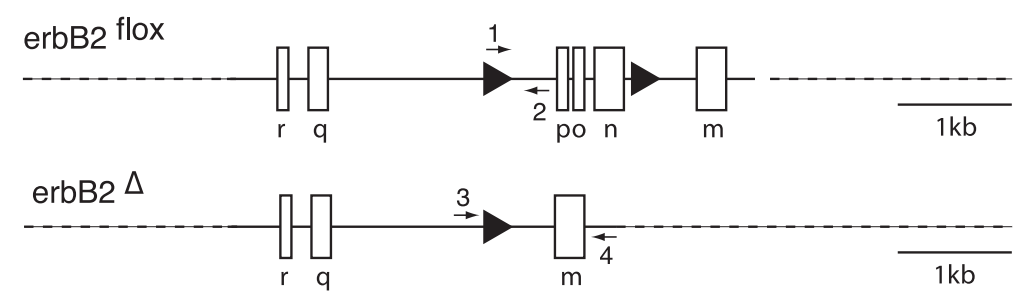

B

C

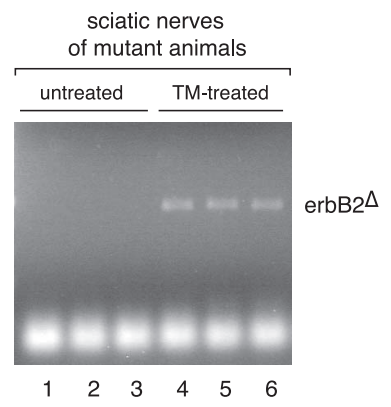

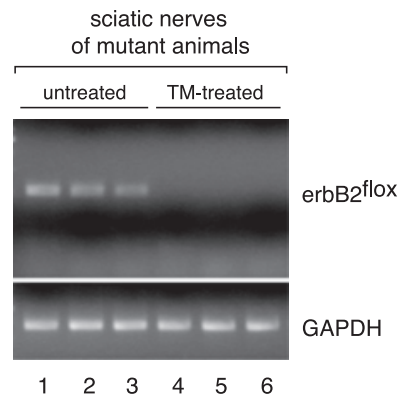

Figure 1. The floxed erbB2 locus is efficiently recombined by the Cre recombinase in Schwann cells of adult peripheral nerves. $A$, Schematic representation of the erbB2 ${ }^{\text {flox }}$ allele with two loxP sites (triangle) flanking three exons (top). The erbB2 $\Delta$ allele (bottom) is obtained after Cre-induced recombination of erbB2 ${ }^{\text {flox }}$. The arrows indicate primers used for PCR analysis. Exons are indicated by boxes and lettered (Garratt et al., 2000). B, PCR detecting the recombined erbB2 $\Delta$ allele in genomic DNA from adult sciatic nerves of three untreated (lanes 1-3) and three TM-treated (lanes 4-6) mutant animals (PLP-CreERT2 erbB2 ${ }^{\text {lacz/flox }}$ ). C, Semiquantitative $P C R$ detecting the non-recombined erbB2 ${ }^{\text {flox }}$ allele in genomic DNA from adult sciatic nerves of three untreated (lanes 1-3) and three TM-treated (lanes 4-6) mutant animals (PLP-CreERT2 erbB2 lacZ/flox). GAPDH serves as internal control. D Western blot analysis of pooled lysates prepared from sciatic nerves of control (con) and mutant (mut) mice. Control nerves were from three PLP-CreERT2 erbB2 ${ }^{\text {wt/flox }}$; mutant nerves were from three PLP-CreERT2 erbB2 ${ }^{\text {lacl/flox }}$ mice. Mice had been treated with TM for 5 consecutive days at the age of 10 weeks and analyzed 2 months later. The membrane was probed with antibodies specific for erbB2 and $\beta$-actin. Note that erbB2 is undetectable in mutant nerves.

erbB2 and erbB3 is coordinately induced (Cohen et al., 1992; Carroll et al., 1997; Kwon et al., 1997), strongly implicating this pathway in Schwann cell mitogenesis after axotomy. We tested this hypothesis with a rigorous genetic approach by deleting erbB2 specifically in Schwann cells of adult mice. Loss of erbB2 in adult myelinating Schwann cells did not influence the maintenance of myelinated peripheral nerves. Furthermore, in contrast to our expectations (Carroll et al., 1997; Kwon et al., 1997; Guertin et al., 2005), lack of erbB2 had no detectable effect on Schwann cell proliferation after nerve injury. We conclude that the signaling pathways that regulate proliferation in Schwann cells after nerve injury are fundamentally different from those identified in development and in culture.

\section{Materials and Methods}

Animals. Hemizygous PLP-CreERT2 mice (Leone et al., 2003) and homozygous erbB2 flox mice (Garratt et al., 2000) have been described previously. The erbB2 ${ }^{\text {wt/lacz }}$ mice used in this study carry an allele that encodes a nonfunctional ErbB2-galactosidase fusion protein lacking the tyrosine kinase domain (Britsch et al., 1998). Hemizygous PLP-CreERT2 mice were crossed with erbB2 ${ }^{\text {wt } / \text { lac }}$ animals to obtain PLP-CreERT2 erbB2 ${ }^{\text {wt/lacZ }}$ double transgenic mice. PLP-CreERT2 erbB2 ${ }^{\text {wt/lacZ }}$ animals were then bred with homozygous erbB2 ${ }^{\text {flox }}$ mice (erbB2 ${ }^{\text {flox/flox }}$ ) to obtain control PLP-CreERT2 erbB2 ${ }^{\text {wt/flox }}$ and experimental PLP-CreERT2 erbB2 $2^{\text {lacZ/flox }}$ mice. The resulting genotypes from this cross were as fol- lows: PLP-CreERT2 erbB2 $2^{\text {lacZ/flox }}$ (one of four; the experimental group), PLP-CreERT2 erbB2 $2^{\text {wt/flox }}$ (one of four; the control group), erbB2 ${ }^{\text {lacZ/flox }}$ (one of four), or erbB2 ${ }^{\text {wt/flox }}$ (one of four). The phenotypes were analyzed on a C57BL/6/129 hybrid background. Tail-derived DNA was analyzed by PCR to identify PLPCreERT2-positive mice (Leone et al., 2003) and to distinguish erbB2 wild-type and lacZ alleles (Britsch et al., 1998). Primers used for detecting PLP-CreERT2 alleles were as follows: $5^{\prime}$-CAC TCT GTG CTT GGT AAC ATG G, and 5' -TGG GAT CCG CCG CAT AAC C $\left(94^{\circ} \mathrm{C}\right.$ for $2 \mathrm{~min}$, 35 times at $94^{\circ} \mathrm{C}$ for $45 \mathrm{~s}, 53^{\circ} \mathrm{C}$ for $30 \mathrm{~s}$, and $72^{\circ} \mathrm{C}$ for $1 \mathrm{~min}$, followed by a final extension at $72^{\circ} \mathrm{C}$ for $5 \mathrm{~min}$ ). Primers used for detecting lacZ alleles were as follows: $5^{\prime}$-CCA CCC TCT CGC TCC AGA TGG TGG A, and 5'-CGG GCC TCT TCG CTA TTA CGG GAG C $\left(94^{\circ} \mathrm{C}\right.$ for 2 min, 35 times at $94^{\circ} \mathrm{C}$ for $45 \mathrm{~s}$, and $72^{\circ} \mathrm{C}$ for $90 \mathrm{~s}$, followed by a final extension at $72^{\circ} \mathrm{C}$ for $5 \mathrm{~min}$ ). To obtain the recombined erbB2 $\Delta$ allele, control and mutant animals received daily intraperitoneal injections of $2 \mathrm{mg}$ of tamoxifen (TM) for 5 consecutive days. Sciatic nerves were injured $10 \mathrm{~d}$ and 10 weeks after the last injection, respectively. For the myelin maintenance experiments, sciatic nerves were collected 2 months after the last injection. Primers used for detecting the erbB2 flox allele were as follows: primer1, CTT CGT ATA ATG TAT GCT ATA CGA AGT TAT, and primer2, GCA GGG CAA TAT TTG TGT CCT T $\left(94^{\circ} \mathrm{C}\right.$ for 2 min, 35 times at $94^{\circ} \mathrm{C}$ for $45 \mathrm{~s}, 57^{\circ} \mathrm{C}$ for $30 \mathrm{~s}$, and $72^{\circ} \mathrm{C}$ for $1 \mathrm{~min}$, followed by a final extension at $72^{\circ} \mathrm{C}$ for $5 \mathrm{~min}$ ); for the erbB2 $\Delta$ allele: primer 3 , AGT GCC TCA TGT GTG CAG TGA GGA C, and primer 4 , TGA GTT ACA GAC CAA GCC GCT CGA G $\left(94^{\circ} \mathrm{C}\right.$ for $2 \mathrm{~min}, 35$ times at $94^{\circ} \mathrm{C}$ for $45 \mathrm{~s}, 53^{\circ} \mathrm{C}$ for $30 \mathrm{~s}$, and $72^{\circ} \mathrm{C}$ for $1 \mathrm{~min}$, followed by a final extension at $72^{\circ} \mathrm{C}$ for $5 \mathrm{~min}$ ). Genomic DNA from sciatic nerves was prepared as described previously (Garratt et al., 2000). The perineurium was stripped from sciatic nerves to minimize contamination by surrounding tissue.

Sciatic nerve transection. The right sciatic nerve of anesthetized mice ( $100 \mathrm{mg} / \mathrm{kg} \mathrm{Ketaminol;} 5 \mathrm{mg} / \mathrm{kg}$ Narcoxyl, i.p.) was exposed at the sciatic notch. The nerve was transected and the two nerve stumps diverted to prevent axonal regeneration into the distal nerve stump. The distal nerve stumps were recovered 4 or $12 \mathrm{~d}$ after transection. Contralateral nerves were used as unlesioned control samples.

Immunofluorescence microscopy. Mice were injected intraperitoneally with bromodeoxyuridine (BrdU) (100 $\mu \mathrm{g} / \mathrm{g}$ body weight) 2 and $1 \mathrm{~h}$ before killing. Nerves were fixed for $30 \mathrm{~min}$ in freshly prepared $4 \%$ paraformaldehyde (in PBS), washed in PBS, incubated in 30\% sucrose in PBS overnight at $4^{\circ} \mathrm{C}$, and embedded in OTC (Miles, Kankakee, IL). Fivemicrometer-thick longitudinal sections were cut at $-20^{\circ} \mathrm{C}$ and mounted on SuperFrost/Plus glass slides (Faust, Schaffhausen, Switzerland) and stored at $-20^{\circ} \mathrm{C}$. Sections were blocked for $1 \mathrm{~h}$ in PBS containing $10 \%$ goat serum, $1 \%$ BSA, and $0.3 \%$ Triton X-100, and incubated with a rabbit antiserum against S100 (1:300; DakoCytomation, Carpinteria, CA) for $16 \mathrm{~h}$ at $4^{\circ} \mathrm{C}$. Slides were rinsed in PBS and incubated with Cy3-conjugated goat anti-rabbit secondary antibody (1:200; Jackson ImmunoResearch, West Grove, PA) for $1 \mathrm{~h}$ at room temperature (RT). Sections were rinsed in PBS, and then fixed in 4\% paraformaldehyde for $10 \mathrm{~min}$ on ice, rinsed in PBS, incubated in methanol for 10 min on ice, rinsed in PBS, incubated in $1 \mathrm{M} \mathrm{HCl}$ at $60^{\circ} \mathrm{C}$ for $7 \mathrm{~min}$, rinsed in PBS, incubated with biotinylated antibody against BrdU (1:10; Caltag Laboratories, South San Francisco, CA) for $1 \mathrm{~h}$ at $37^{\circ} \mathrm{C}$, rinsed, and incubated with streptavidin-FITC (1:400; 
Jackson ImmunoResearch) for $1 \mathrm{~h}$ at RT. Controls with secondary antibodies only showed negligible stainings. Sections were mounted in AF1 (Citifluor, Canterbury, UK) supplemented with $4^{\prime}, 6^{\prime}$ diamidino-2-phenylindole (1:1000; Roche, Basel, Switzerland). Immunoreactivity was visualized by epifluorescence microscopy and documented using a Hamamatsu (Hamamatsu City, Japan) Color Chilled 3CCD camera. Images were processed with Adobe Photoshop 7.0 for Macintosh.

Statistical analysis. Three animals per genotype were analyzed, and the individual who counted was blinded to the genotype of the mice. BrdUpositive cells were counted in two adjacent $40 \times$ objective fields, each covering an area of $0.25 \mathrm{~mm}^{2}, \sim 2.5-3.0 \mathrm{~mm}$ distal to the site of transection. To avoid possible differences in cell size or sampling biases, six random sections from different levels within a nerve were examined. A total of $\sim 1000$ S100-positive cells per nerve and mouse have been analyzed. The percentage of S100/BrdU-positive cells was determined (mean $\pm \mathrm{SD}$ ) and the values transformed with arcsin[sqrt(percentage/ 100)]. The transformed values were compared using the two-tailed unpaired Student's $t$ test.

Western blotting. Sciatic nerve tissue was dissected from killed mice, frozen in liquid nitrogen, pulverized with a chilled mortar and pestle, and dissolved in SDS gel sample buffer (Atanasoski et al., 2004). Nerves of at least three mice per genotype were pooled, and two pools were analyzed in duplicate. Proteins were electrophoresed on 5\% SDS-polyacrylamide gels, transferred onto polyvinylidene difluoride membrane, and immunoblotted with antibodies against epidermal growth factor receptor (EGFR)/erbB1 (NeoMarkers, Fremont, CA) at 1:1500 dilution, erbB2 (Santa Cruz Biotechnology, Santa Cruz, CA) at 1:100 dilution, erbB3 (Santa Cruz Biotechnology) at 1:100 dilution, erbB4 (a kind gift from Cary Lai, The Scripps Research Institute, La Jolla, CA) at 1:5000 dilution, mitogen-activated protein kinase (MAPK) (Cell Signaling, Beverly, MA) at 1:1000 dilution, phosphorylated MAPK (MAPK-P) (Cell Signaling) at 1:1000 dilution, cyclin D1 (Santa Cruz Biotechnology) at 1:100 dilution, and $\beta$-actin (Sigma, St. Louis, MO) at 1:500 dilution. After incubating with goat anti-rabbit horseradish peroxidase- (Santa Cruz Biotechnology) or goat anti-mouse $\kappa$ chain alkaline phosphatase-conjugated secondary antibodies (Southern Biotechnology, Birmingham, AL), the immunoreactive bands were visualized by Western Lightning (PerkinElmer Life Sciences, Wellesley, MA) or CDP-Star (Roche), respectively. The blots were quantified using the ImageJ software (http://rsb.info.nih.gov/ ij/), normalizing the individual lanes to the $\beta$-actin signal.

Light microscopy. Mice were killed, and sciatic nerves were removed and placed in fixative ( $3 \%$ glutaraldehyde on $0.1 \mathrm{~m}$ phosphate buffer, $\mathrm{pH}$ 7.4) overnight at $4^{\circ} \mathrm{C}$. The samples were washed twice in $0.1 \mathrm{M}$ phosphate buffer, $\mathrm{pH} 7.4$, placed in $2 \%$ osmium tetroxide in $0.1 \mathrm{M}$ phosphate buffer, rinsed in water, dehydrated with successively increasing percentages of ethanol $(25,35,50,70,80,95$, and $100 \%)$ followed by propylene oxide, infiltrated in 50 and $75 \%$ epoxy in propylene oxide, and then 100\% epoxy overnight, embedded in fresh epoxy, and hardened in a $60^{\circ} \mathrm{C}$ oven. Semithin sections $(500 \mathrm{~nm})$ were stained with $1 \%$ toluidine blue and photographed on a Leica (Nussloch, Germany) DMR microscope using a cooled Hamamatsu camera. Images were scanned and manipulated in Adobe Photoshop. The observer (S. S. Scherer) was blinded to the genotype of the mice.

$\mathrm{g}$ ratio determinations. Semithin sections of a peroneal nerve from each of three control (Cre; erbB2 wt/flox) and three mutant (Cre; erbB2 lacZ/ flox) mice were imaged on a Leica DM microscope with a $100 \times$ oil immersion lens. For each nerve, one of the captured images was analyzed with OpenLab software, using a Wacom Intuos $3(9 \times 12)$ digital tablet to trace all of the myelinated axons in the image, excluding those with regions of uncompacted myelin. For each myelinated axon, the diameter of the axon and the outer diameter of the compact myelin sheath were traced. These data were transferred to a Microsoft (Redmond, WA) Excel spreadsheet and used to calculate a $g$ ratio (the axon diameter/total diameter) for each axon. The $g$ ratios of the control and mutant nerves were plotted, and a one-tailed Student's $t$ test was performed. No statistical difference was found $(p=0.11)$.

\section{Results}

\section{Efficient ablation of erbB2 in adult Schwann cells of} peripheral nerves

In this study, we have used a TM-inducible variant of the Cre recombinase (CreERT2) (Metzger et al., 1995; Feil et al., 1996) as a transgene under the control of mouse proteolipid protein (Plp) gene regulatory elements. This transgene can be specifically activated in Schwann cells in vivo to allow loxP site-mediated recombination (Leone et al., 2003). PLP-CreERT2 animals were crossed with erbB2 ${ }^{\text {wt } / \text { lac }}$ mice (the erbB2 $2^{\text {lac }}$ allele represents a null allele). Resulting PLP-CreERT2 erbB2 ${ }^{\text {wt } / \text { lacZ }}$ animals were mated with mice homozygous for the conditional erbB2 allele $\left(e r b B 2^{\text {flox/flox }}\right)$ in which loxP sites flank exons encoding crucial parts of the extracellular domain of the receptor (Fig. 1A) (Garratt et al., 2000). This strategy yielded PLP-CreERT2 erbB2 ${ }^{\text {flox/lacZ }}$ mice (experimental/mutant group) and PLP-CreERT2 erbB2 ${ }^{\text {flox/wt }}$ mice (control group).

Based on our previous optimization studies (Leone et al., 2003), 10-week-old mice received daily intraperitoneal injections of $2 \mathrm{mg}$ of TM for 5 consecutive days to activate the Cre-ERT2 fusion protein and to delete the floxed erbB2 allele (erbB2 $\Delta)$, present in both control and mutant mice (Fig. 1A). Genomic DNA from mutant sciatic nerves of treated mice was analyzed 2 months after the last TM injection to verify genomic deletion at the erbB2 locus (Fig. $1 B, C$ ). A 500 bp product corresponding to the deleted erbB2 allele (erbB2 $\Delta$ ) appeared exclusively in the PCR analysis of sciatic nerve DNA from individual TM-treated mutant animals (Fig. 1B, lanes 4-6) but not in the DNA of untreated

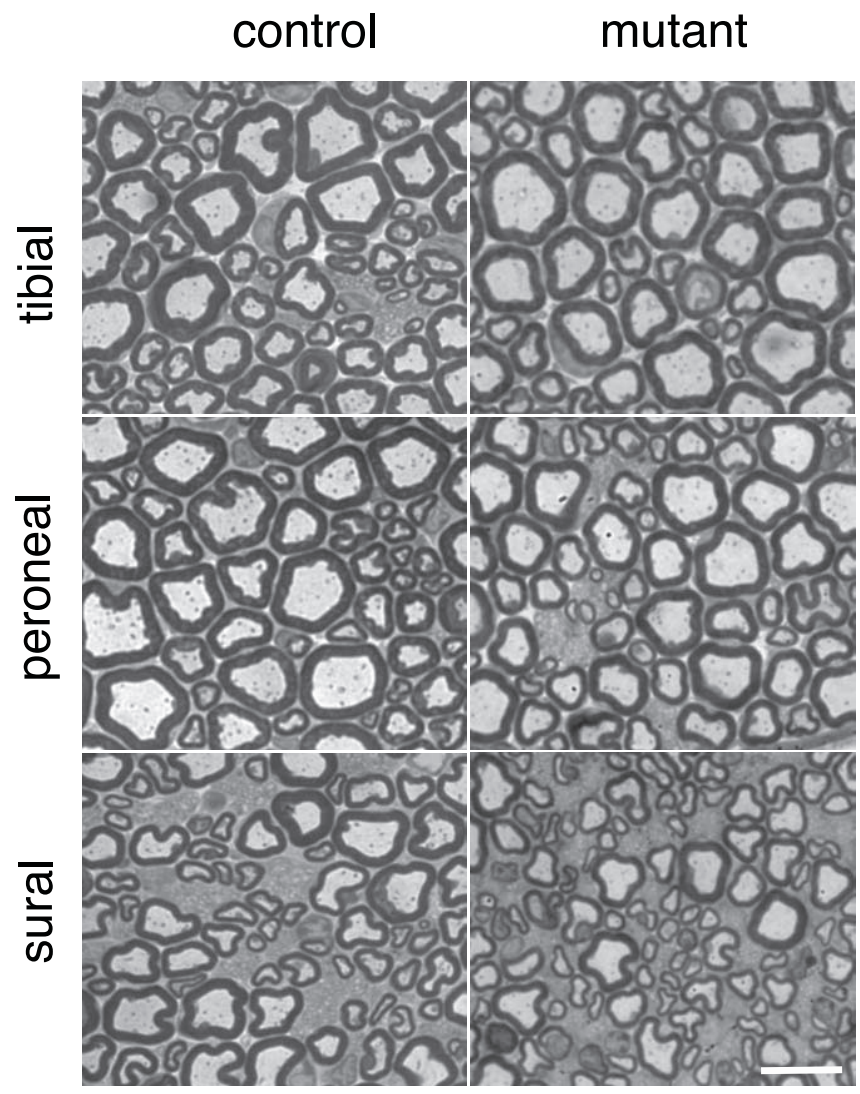

Figure 2. Myelinated peripheral nerves are maintained in the absence of erbB2. These are images of transverse semithin sections of adult mouse nerves stained with toluidine blue. The tibial, peroneal, and sural branches of the sciatic nerve are shown for one control and one mutant mouse, 10 weeks after TM induction. Scale bar, $10 \mu \mathrm{m}$. 
A
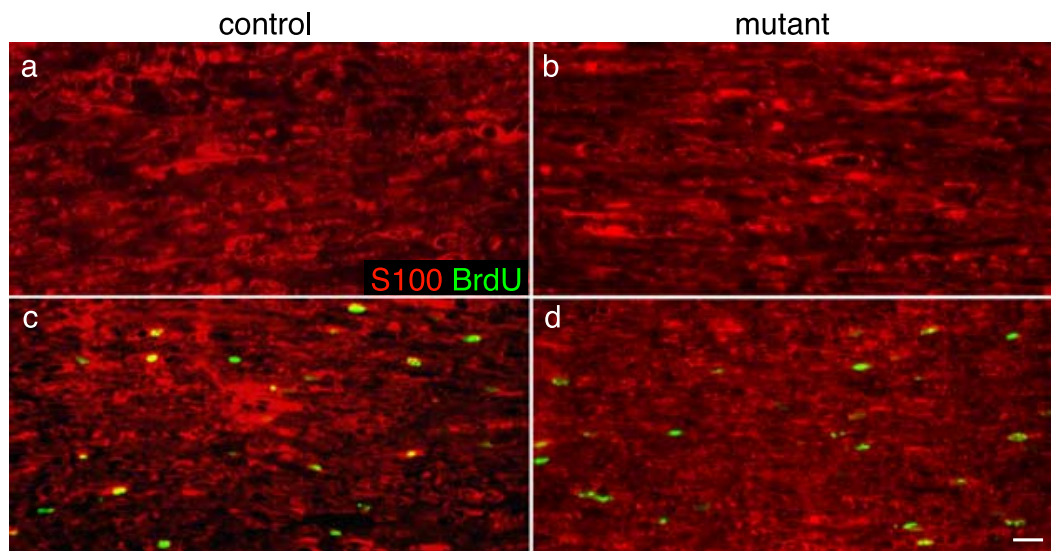

B

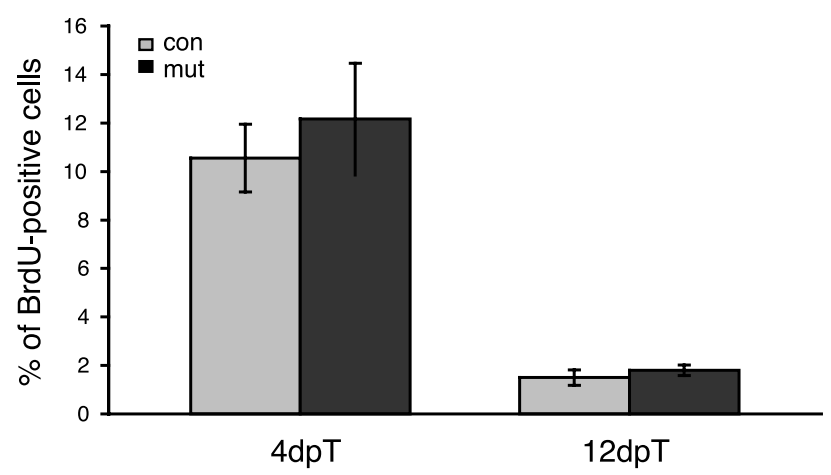

Figure 3. ErbB2-mediated signaling is not required for injury-induced proliferation of $S$ chwann cells. $A$, Images of longitudinal sections of uninjured $(\boldsymbol{a}, \boldsymbol{b})$ and the distal stumps of injured $(4 \mathrm{dpT} ; \boldsymbol{c}, \boldsymbol{d})$ sciatic nerves, double-labeled with an anti-BrdU monoclonal antibody (green) and a rabbit antiserum against the Schwann cell marker $S 100 \beta$ (red). Nerves were taken from control ( $\boldsymbol{a}$, c) and mutant $(\boldsymbol{b}, \boldsymbol{d})$ animals; control nerves were from PLP-CreERT2 erbB2 ${ }^{\text {wt/flox; }}$; mutant nerves were from PLP-CreERT2 erbB2 ${ }^{\text {lacz/flox }}$ mice. All mice had been treated with TM for 5 consecutive days at 10 weeks of age. Surgery was performed $10 \mathrm{~d}$ after the last TM injection. Note that the number of BrdU-positive nuclei is similar in mutants and control animals at 4dpT. Contralateral, unlesioned nerves contain no labeled cells. Scale bar, $40 \mu \mathrm{m}$. B, Quantitative analysis of cell proliferation in control (con) (gray bar) and mutant (mut) (black bar) sciatic nerves $4 \mathrm{dpT}$ and $12 \mathrm{dpT}$. Data are mean values obtained from three animals per time point and genotype. There is no significant difference between the control and mutant nerves by Student's $t$ test. Error bars indicate SD.

mutant mice (Fig. 1B, lanes 1-3). Conversely, the amount of a $200 \mathrm{bp}$ product, corresponding to the $\mathrm{erbB2} 2^{\text {flox }}$ allele, was markedly reduced after TM treatment of mutant animals (Fig. 1C, compare lanes $1-3$ with lanes $4-6$ ). Western blot analysis using nerve lysates from three pooled animals per genotype revealed that protein levels of erbB2 were not detectable in mutant compared with control nerves, 2 months after the last TM injection (Fig. $1 D$ ). We conclude that we have achieved highly efficient induced recombination of the floxed erbB2 gene, leading to strongly reduced levels of erbB2 protein in adult sciatic nerves.

\section{Myelinated peripheral nerves are maintained and not} detectably altered after erbB2 ablation in adult Schwann cells Next, we examined whether loss of erbB2 in adult Schwann cells affects the maintenance of myelinated peripheral nerves. Figure 2 shows semithin cross sections of PLP-CreERT2 erbB2 $2^{\text {flox/wt }}$ and PLP-CreERT2 erbB2 ${ }^{\text {flox/lacZ }}$ adult sciatic nerves 2 months after TM treatment. An observer who was blinded to the genotypes of the mice could not detect differences in the structure or in the degree of myelination when examining the tibial, peroneal, and sural branches of three mutants and three control mice; all looked normal. Figure 2 shows examples from a mutant and a control mouse. To corroborate these observations, the $g$ ratios of the control and mutant nerves were determined, and no significant differences were found (supplemental figure, available at www. jneurosci.org as supplemental material). These findings indicate that Schwann cellexpressed erbB2 is not required for the maintenance of myelinated axons in adult peripheral nerves.

Schwann cell proliferation in Wallerian degeneration is not affected in adult erbB2-conditional null nerves

The finding that erbB2-deficient nerves appeared to be normal allowed us to examine the specific potential requirement for neuregulin/erbB signaling in proliferation and survival of adult Schwann cells in Wallerian degeneration. For this analysis, we examined longitudinal sections of the distal nerve stump at $4 \mathrm{~d}$ posttransection (4dpT), when Schwann cell proliferation is highest (Bradley and Asbury, 1970) and 12dpT, when erbB2 protein levels are high (Carroll et al., 1997; Kwon et al., 1997). We induced erbB2 ablation with TM in three control and three mutant mice, and transected one sciatic nerve $10 \mathrm{~d}$ after the last TM injection. Mitotically active Schwann cells were labeled by pulsing with BrdU at $4 \mathrm{dpT}$ or $12 \mathrm{dpT}$. No BrdU-labeled Schwann cells were seen in uninjured controls or mutant nerves, whereas we found numerous BrdUlabeled cells in lesioned nerves of both genotypes $4 \mathrm{dpT}$ (Fig. $3 A$ ). Double labeling with the marker protein $S 100 \beta$ demonstrated that the BrdU-positive cells were Schwann cells. We counted at least 1000 Schwann cells per mouse and determined that, at $4 \mathrm{dpT}$ and $12 \mathrm{dpT}$, there were no significant differences in BrdU-positive cells between control and mutant nerves (Fig. 3B).

Because erbB2 signaling is also required for cell survival during development (Jessen et al., 1994; Grinspan et al., 1996; Garratt et al., 2000), we tested whether erbB2 ablation in adult Schwann cells causes increased apoptosis. No apoptotic cells were detected in control or mutant nerves, neither before nor after axotomy (data not shown).

To corroborate our results, we also ablated erbB2 using a second mouse line expressing CreERT2 under the control of the Schwann cell-specific Mpz/P0 promoter and regulatory regions of the human connexin32 gene (P0Cx-CreERT2) (Leone et al., 2003). Again, we found no differences in either the proliferation or the apoptosis of Schwann cells after axotomy between erbB2deficient versus control mice (data not shown).

To determine the efficiency of erbB2 protein loss at $4 \mathrm{dpT}$, Western blots of nerve lysates from two pools of four pooled animals per genotype were probed for erbB2, erbB3, and $\beta$-actin (Fig. 4A). The level of erbB2 in mutant animals was strongly 
reduced compared with control nerves in lesioned and unlesioned nerves (Fig. $4 A, B)$. Note that, as expected (Cohen et al. 1992; Carroll et al. 1997), the erbB2 level in lesioned control nerves was higher than in unlesioned control nerves (Fig. 4A,B). ErbB3 levels were not affected by the ablation of erbB2, neither in unlesioned nor lesioned nerves (Fig. 4A). Thus, conditional disruption of the erbB2 gene in adult Schwann cells results in drastically reduced erbB2 levels at $4 \mathrm{dpT}$ without significant effects on cell proliferation or survival during early and late Wallerian degeneration.

We next examined the possibility that the residual erbB2 protein expressed in injured nerves $10-14 \mathrm{~d}$ after the last TM injection (Fig. 4A) might account for the unchanged proliferative response of Schwann cells in mutant mice (Fig. 3). Based on our myelin maintenance studies, we waited 10 weeks after the last TM injection to achieve nondetectable levels of erbB2 in Schwann cells (Fig. 1D) before injuring three control and three mutant sciatic nerves. Again, there were no significant differences in BrdU-positive cells between control and mutant nerves (data not shown). These results corroborate our finding, that erbB2 signaling is largely dispensable for proliferation after nerve axotomy.

\section{EGFR/erbB1 and erbB4 do not compensate for the loss of erbB2}

To test the possibility that other erbB receptor family members compensate for the loss of erbB2, we analyzed the expression of EGFR/erbB1 (Ullrich et al., 1984; Carpenter, 1987) and erbB4 (Lai and Lemke, 1991; Plowman et al., 1993) in mutant and control groups of lesioned and unlesioned sciatic nerves by Western blotting (Fig. 4C). EGFR1/erbB1 and erbB4 were not detectably expressed in normal (Cohen et al., 1992; Levi et al., 1995; Grinspan et al., 1996) and mutant sciatic nerves, regardless of lesions, indicating that there was no major compensation by these related receptors.

\footnotetext{
Ablation of erbB2 in adult Schwann cells alters the levels of active MAPK and cyclin D1

Puzzled by the unexpected findings, we examined whether downstream signaling molecules of the neuregulin/erbB pathway are affected by the erbB2 mutation. Nerve lysates of four mice per genotype were pooled and two pools were analyzed for the expression of MAPK-P, total MAPK, and $\beta$-actin (Fig. $5 A$ ), and cyclin D1 and $\beta$-actin (Fig. 5C). MAPK-P levels were normalized to total levels of MAPK (Fig. 5B). As expected, the level of MAPK-P in lesioned nerves $4 \mathrm{dpT}$ was higher than that in unlesioned, contralateral nerves, in which Schwann cells are not proliferating (Fig. 5A,B). Interestingly, MAPK-P levels were significantly reduced in mutant compared with control nerves $4 \mathrm{dpT}$
}

C
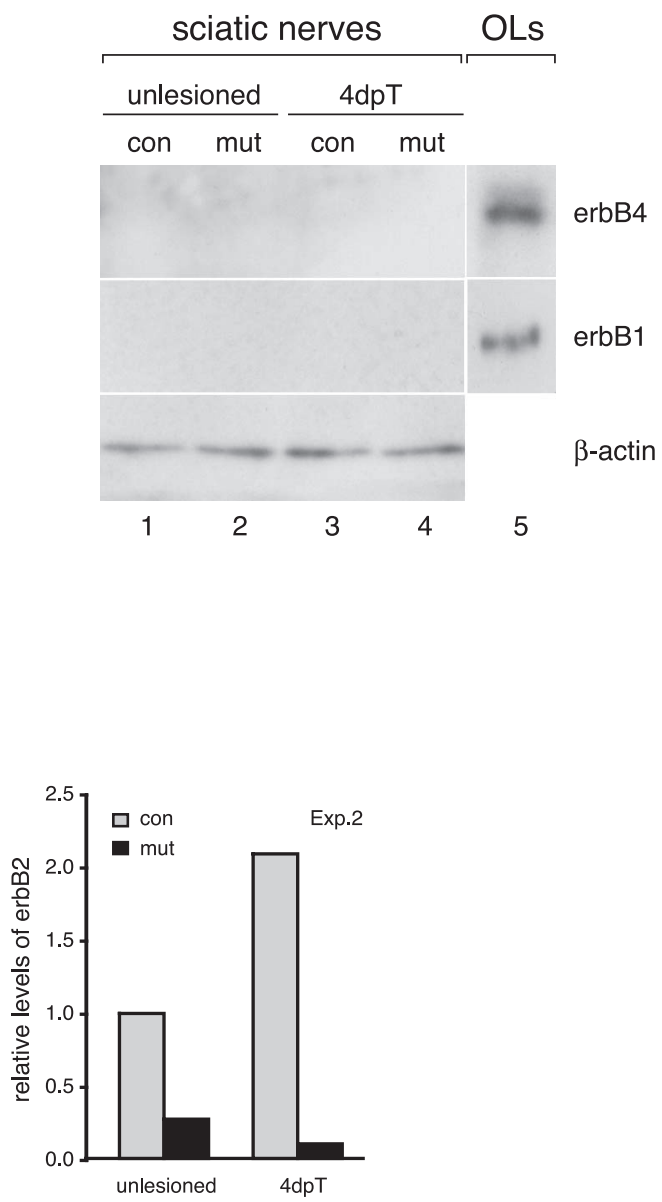

Figure 4. A, Western blot analysis of lysates prepared from uninjured nerves (lanes 1 and 2 ) and from adult sciatic nerves $4 \mathrm{dpT}$ erbB2 lacz/flox mice. All mice had been treated with TM for 5 consecutive days at 10 weeks of age, and surgery was performed $10 \mathrm{~d}$ after the last TM injection. Membranes were probed with antibodies specific for erbB2, erbB3, and $\beta$-actin. $\boldsymbol{B}$, Quantitative

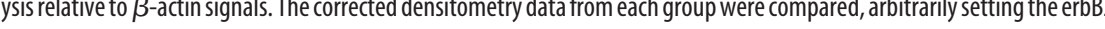
antibodies specific for erbB4, erbB1, and $\beta$-actin. Protein extract of cultured oligodendrocytes (OLs) expressing both erbB4 and erbB1 was used as a positive control (lane 5).

(Fig. 5A,B). Similarly, the amount of cyclin D1 in mutant mice was reduced compared with control nerves (Fig. $5 C, D$ ). We conclude that downstream signaling molecules of the erbB2 pathway are affected after ablation of erbB2 without apparent consequences for the proliferation or survival of Schwann cells during Wallerian degeneration.

\section{Discussion}

Neuregulin/erbB signaling is critically involved in several fundamentally important aspects of peripheral nerve development. In this study, we focused specifically on a potential role of this important signaling pathway in the regulation of adult Schwann cell proliferation after nerve injury. By disrupting this pathway in peripheral nerves in a spatially and temporally controlled manner in vivo, we were able to show that major neuregulin signaling through erbB2 is not an absolute requirement for the regulation of injury-induced Schwann cell proliferation. Furthermore, we found that erbB2 function is mostly dispensable for the mainte- 

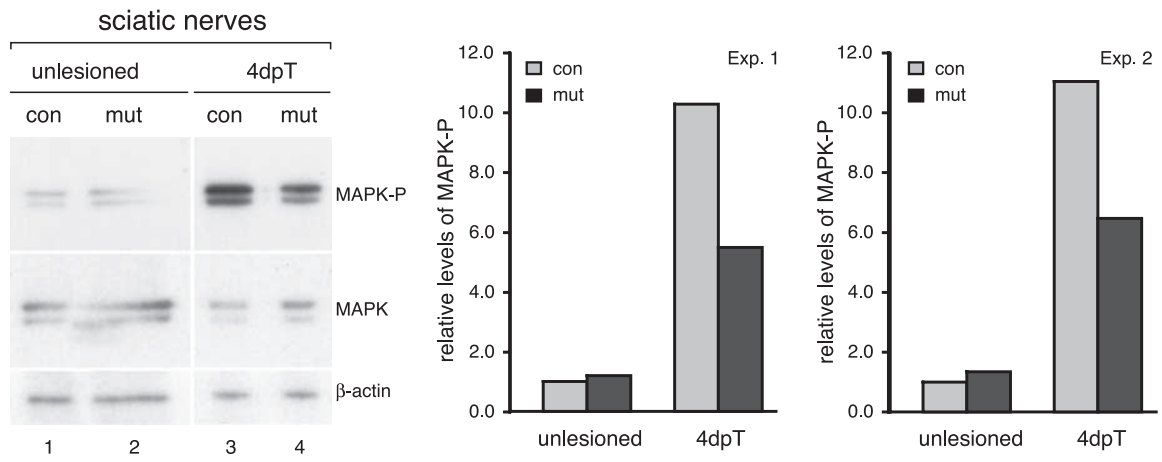

C
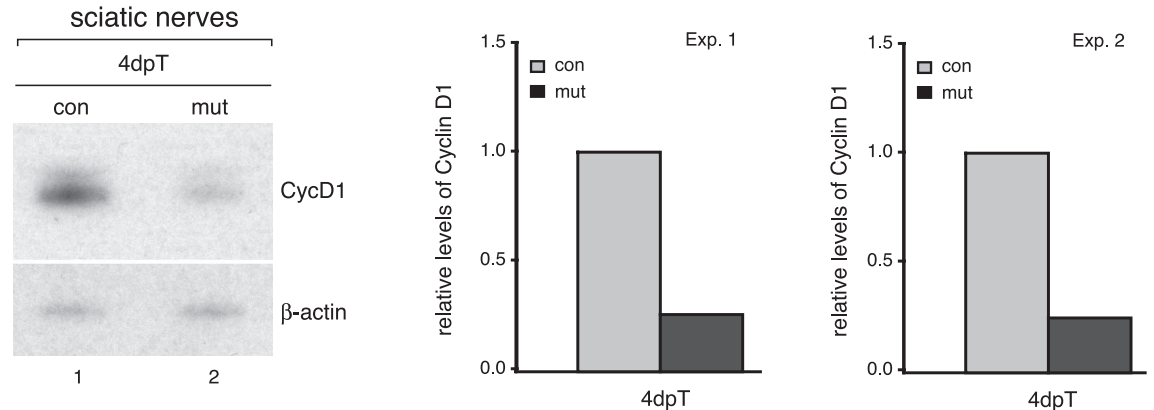

Figure 5. Lowered levels of activated MAPK and cyclin D1 in erbB2-conditional null nerves. $A$, Western blot analysis of pooled uninjured (lanes 1 and 2 ) and injured (4dpT; lanes 3 and 4) sciatic nerves from adult control and mutant mice as described in Figure 4A. Membrane was probed with antibodies specific for MAPK-P (top), total MAPK (middle), and $\beta$-actin (bottom). $\boldsymbol{B}$, The amount of MAPK-P was corrected for unequal total MAPK signals. The corrected densitometry data from each group were compared, arbitrarily setting the MAPK-P signal for unlesioned control adult nerves to 1.0. Nerves of four mice per genotype were pooled and two pools were analyzed (Exp. 1 and 2). C, Western blot analysis of pooled injured sciatic nerves (4dpT) from adult control (lane 1) and mutant (lane 2) mice. The membrane was probed with antibodies specific for cyclin D1 (CycD1) and $\beta$-actin. D, Quantification of the signals shows a significant decrease in cyclin D1 levels in injured mutant nerves. Nerves of four mice per genotype were pooled, and two pools were analyzed (Exp. 1 and 2). con, Control; mut, mutant.

nance of myelinated peripheral nerves. These combined findings support our previous results (Atanasoski et al., 2002, 2006) that the molecular control and requirements for proper Schwann cell function differ fundamentally during development and after nerve damage.

We have demonstrated previously that the TM-induced recombination efficiency in Schwann cells of PLP-CreERT2 animals, crossed with mice carrying the Rosa26-LacZ reporter, is $\sim 80 \%$ (Leone et al., 2003). Because recombination frequencies can vary between different alleles carrying loxP sites (Vooijs et al., 2001), it was important to determine the efficiency of gene ablation in sciatic nerves after TM-induced recombination at another locus. In the present study, we observed almost complete recombination at the erbB2 locus indicating high efficiency. This was accompanied by $\sim 75 \%$ reduction of erbB2 protein in uninjured nerves 2 weeks after TM injection. Because erbB2 was only ablated in Schwann cells, the remaining erbB2 expression may originate from contamination by surrounding tissue (Pearson and Carroll, 2004) and blood vessels (Russell et al., 1999) (data not shown), which continue to express erbB2. However, a slow turnover of erbB2 is a more likely explanation, because the amount of erbB2 in mutants compared with controls is decreased from $\sim 25 \%$ in uninjured to $\sim 12 \%$ in injured nerves when protein turnover is generally accelerated because of the breakdown and the phagocytosis of the myelin sheath. In addition, erbB2 protein was not detectable in mutant nerves 2 months after TM administration.

Schwann cells express only erbB2 and erbB3 but not detectable erbB1 or erbB4 (Vartanian et al., 1997) as confirmed in this study. Unlike the other family members, the intrinsic tyrosine kinase of erbB3 is catalytically inactive; active signaling depends on heterodimer formation with erbB1, erbB2, or erbB4 (Vartanian et al., 1997). Thus, by ablating erbB2 in Schwann cells, signal transduction by neuregulins is inhibited, unless other receptor tyrosine family members compensate for the loss of erbB2. However, we found no detectable expression of erbB1 or erbB4 in erbB2-deficient Schwann cells, so that neuregulin signaling should have been strongly impaired.

The question remains as to how the observed differences between the requirements for the neuregulin/erbB signaling system during development and after injury are controlled. During the early postnatal phase, Schwann cell survival and proliferation is regulated, in part, by access to axonally derived neuregulin-1 (Wolpowitz et al., 2000) and axotomyinduced Schwann cell death during development can be rescued by exogenous neuregulin-1 (Grinspan et al., 1996; Trachtenberg and Thompson, 1996). In adult mice, the apoptotic response of Schwann cells after axonal damage is limited (Grinspan et al., 1996; Atanasoski et al., 2006), and neuregulin isoforms are predominantly expressed by Schwann cells (Carroll et al., 1997). These differences might account for the observed discrepancies between neuregulin/erbB functions in development and after nerve injury. Conditional erbB2 ablation in immature Schwann cells using a Krox20-cre allele leads to an increase of proliferating and apoptotic cells in postnatal developing nerves (Garratt et al., 2000). We also injured adult nerves of Krox 20 -cre erbB2 ${ }^{\text {flox }}$ mice and, similar to the processes described during development (Garratt et al., 2000), we found increased Schwann cell proliferation and cell death after nerve damage compared with controls (our unpublished data). In contrast, ablating erbB2 exclusively in adult Schwann cells of fully myelinated peripheral nerves has no detectable effect on survival and cell division after injury. Thus, Schwann cell responses to axotomy depend on the timing of erbB2 ablation.

Analysis of neuregulin and erbB receptor expression in peripheral nerve undergoing Wallerian degeneration demonstrated that both ligands and receptors are not only expressed during the proliferation period but also throughout a subsequent time of markedly diminished Schwann cell mitogenesis (Carroll et al., 1997). This raises the question of whether neuregulin/erbB signaling plays a role in later stages of Wallerian degeneration. We 
did not observe differences in proliferation or survival of Schwann cells $12 \mathrm{~d}$ posttransection when erbB2 levels are high in wild-type nerves. However, it remains to be determined whether erbB2 plays a role in remyelination, similar to its function in myelination during normal development.

Despite the finding that proliferation rates are not altered in conditional erbB2-null nerves after injury, we observed reduced levels of signaling molecules involved in the erbB2 pathway triggering proliferation, such as phosphorylated MAPK and cyclin D1 (Rahmatullah et al., 1998). We hypothesize that these molecules were not sufficiently suppressed to abolish proliferation. Alternatively, PI3-K (phosphatidylinositol 3-kinase), which has been shown to promote Schwann cell proliferation (Maurel and Salzer, 2000), might be involved in this paradigm. Furthermore, extracellular factors other than neuregulins may contribute to the regulation of Schwann cell proliferation and survival after axonal damage and/or compensate for the loss of neuregulin/erbB function. TGF $\beta$ might be a candidate because it is involved in the regulation of Schwann cell proliferation, survival, and differentiation (Ridley et al., 1989; Mews and Meyer, 1993; Einheber et al., 1995; Guenard et al., 1995; Parkinson et al., 2001; Awatramani et al., 2002; Day et al., 2003; Atanasoski et al., 2004). It remains to be seen whether interrupting this signaling pathway will have an impact on proliferation of adult Schwann cells after injury. Other mitogens that may play a role include PDGF (Hardy et al., 1992), NT-3 (neurotrophin 3) (Funakoshi et al., 1993), and IGF (Sondell et al., 1997).

In summary, efficient Schwann cell-specific ablation of erbB2 in adult mice using two different CreERT2 lines has no detectable effects on the maintenance of myelinated peripheral nerves or on proliferation and survival of adult Schwann cells after injury. These findings are in sharp contrast to the observed developmental deficits when erbB2 is ablated in immature Schwann cells, strongly suggesting that the molecular control of Schwann cell proliferation is different during development than after nerve injury. It will be an exciting task to define the crucial signaling pathways that regulate Schwann cell proliferation after lesion.

\section{References}

Atanasoski S, Shumas S, Dickson C, Scherer SS, Suter U (2001) Differential cyclin D1 requirements of proliferating Schwann cells during development and after injury. Mol Cell Neurosci 18:581-592.

Atanasoski S, Scherer SS, Nave KA, Suter U (2002) Proliferation of Schwann cells and regulation of cyclin D1 expression in an animal model of Charcot-Marie-Tooth disease type 1A. J Neurosci Res 67:443-449.

Atanasoski S, Notterpek L, Lee HY, Castagner F, Young P, Ehrengruber MU, Meijer D, Sommer L, Stavnezer E, Colmenares C, Suter U (2004) The protooncogene ski controls Schwann cell proliferation and myelination. Neuron 43:499-511.

Atanasoski S, Boller D, De Ventura L, Koegel H, Boentert M, Young P, Werner S, Suter U (2006) Cell cycle inhibitors p21 and p16 are required for the regulation of Schwann cell proliferation. Glia 53:147-157.

Awatramani R, Shumas S, Kamholz J, Scherer SS (2002) TGFbetal modulates the phenotype of Schwann cells at the transcriptional level. Mol Cell Neurosci 19:307-319.

Berger AR, Schaumburg HH (1995) Human peripheral nerve disease. In: The axon (Waxman SG, Kocsis JD, Stys PK, eds), pp 648-660. New York: Oxford UP.

Bradley WG, Asbury AK (1970) Duration of synthesis phase in neuilemma cells in mouse sciatic nerve during degeneration. Exp Neurol 26:275-282.

Britsch S, Li L, Kirchhoff S, Theuring F, Brinkmann V, Birchmeier C, Riethmacher D (1998) The ErbB2 and ErbB3 receptors and their ligand, neuregulin-1, are essential for development of the sympathetic nervous system. Genes Dev 12:1825-1836.

Carpenter G (1987) Receptors for epidermal growth factor and other polypeptide mitogens. Annu Rev Biochem 56:881-914.

Carroll SL, Miller ML, Frohnert PW, Kim SS, Corbett JA (1997) Expression of neuregulins and their putative receptors, ErbB2 and ErbB3, is induced during Wallerian degeneration. J Neurosci 17:1642-1659.

Chan R, Hardy WR, Dankort D, Laing MA, Muller WJ (2004) Modulation of ErbB2 signaling during development: a threshold level of ErbB2 signaling is required for development. Development 131:5551-5560.

Cohen JA, Yachnis AT, Arai M, Davis JG, Scherer SS (1992) Expression of the neu proto-oncogene by Schwann cells during peripheral nerve development and Wallerian degeneration. J Neurosci Res 31:622-634.

Day WA, Koishi K, McLennan IS (2003) Transforming growth factor beta 1 may regulate the stability of mature myelin sheaths. Exp Neurol 184:857-864

Dong Z, Brennan A, Liu N, Yarden Y, Lefkowitz G, Mirsky R, Jessen KR (1995) Neu differentiation factor is a neuron-glia signal and regulates survival, proliferation, and maturation of rat Schwann cell precursors. Neuron 15:585-596.

Einheber S, Hannocks MJ, Metz CN, Rifkin DB, Salzer JL (1995) Transforming growth factor-beta 1 regulates axon/Schwann cell interactions. J Cell Biol 129:443-458.

Feil R, Brocard J, Mascrez B, LeMeur M, Metzger D, Chambon P (1996) Ligand-activated site-specific recombination in mice. Proc Natl Acad Sci USA 93:10887-10890.

Funakoshi H, Frisen J, Barbany G, Timmusk T, Zachrisson O, Verge VM, Persson H (1993) Differential expression of mRNAs for neurotrophins and their receptors after axotomy of the sciatic nerve. J Cell Biol 123:455-465.

Garratt AN, Voiculescu O, Topilko P, Charnay P, Birchmeier C (2000) A dual role of erbB2 in myelination and in expansion of the Schwann cell precursor pool. J Cell Biol 148:1035-1046.

Griffin JW, Hoffman PN (1993) Degeneration and regeneration in the peripheral nervous system. In: Peripheral neuropathies, Ed 3 (Dyck PJ, Thomas PK, Griffin JW, Low PA, Podulso JF, eds), pp 361-376. Philadelphia: Saunders.

Grinspan JB, Marchionni MA, Reeves M, Coulaloglou M, Scherer SS (1996) Axonal interactions regulate Schwann cell apoptosis in developing peripheral nerve: neuregulin receptors and the role of neuregulins. J Neurosci 16:6107-6118.

Guenard V, Gwynn LA, Wood PM (1995) Transforming growth factor-beta blocks myelination but not ensheathment of axons by Schwann cells in vitro. J Neurosci 15:419-428.

Guertin AD, Zhang DP, Mak KS, Alberta JA, Kim HA (2005) Microanatomy of axon/glial signaling during Wallerian degeneration. J Neurosci 25:3478-3487.

Hardy M, Reddy UR, Pleasure D (1992) Platelet-derived growth factor and regulation of Schwann cell proliferation in vivo. J Neurosci Res $31: 254-262$.

Ho WH, Armanini MP, Nuijens A, Phillips HS, Osheroff PL (1995) Sensory and motor neuron-derived factor. A novel heregulin variant highly expressed in sensory and motor neurons. J Biol Chem 270:26722.

Jessen KR, Mirsky R (2005) The origin and development of glial cells in peripheral nerves. Nat Rev Neurosci 6:671-682.

Jessen KR, Brennan A, Morgan L, Mirsky R, Kent A, Hashimoto Y, Gavrilovic J (1994) The Schwann cell precursor and its fate: a study of cell death and differentiation during gliogenesis in rat embryonic nerves. Neuron 12:509-527.

Jin JJ, Nikitin A, Rajewsky MF (1993) Schwann cell lineage-specific neu (erbB-2) gene expression in the developing rat nervous system. Cell Growth Differ 4:227-237.

Kim HA, Pomeroy SL, Whoriskey W, Pawlitzky I, Benowitz LI, Sicinski P, Stiles CD, Roberts TM (2000) A developmentally regulated switch directs regenerative growth of Schwann cells through cyclin D1. Neuron 26:405-416.

Kwon YK, Bhattacharyya A, Alberta JA, Giannobile WV, Cheon K, Stiles CD, Pomeroy SL (1997) Activation of ErbB2 during Wallerian degeneration of sciatic nerve. J Neurosci 17:8293-8299.

Lai C, Lemke G (1991) An extended family of protein-tyrosine kinase genes differentially expressed in the vertebrate nervous system. Neuron 6:691-704.

Leone DP, Genoud S, Atanasoski S, Grausenburger R, Berger P, Metzger D, Macklin WB, Chambon P, Suter U (2003) Tamoxifen-inducible gliaspecific Cre mice for somatic mutagenesis in oligodendrocytes and Schwann cells. Mol Cell Neurosci 22:430-440.

Levi AD, Bunge RP, Lofgren JA, Meima L, Hefti F, Nikolics K, Sliwkowski MX 
(1995) The influence of heregulins on human Schwann cell proliferation. J Neurosci 15:1329-1340.

Maurel P, Salzer JL (2000) Axonal regulation of Schwann cell proliferation and survival and the initial events of myelination requires PI 3-kinase activity. J Neurosci 20:4635-4645.

Metzger D, Clifford J, Chiba H, Chambon P (1995) Conditional sitespecific recombination in mammalian cells using a ligand-dependent chimeric Cre recombinase. Proc Natl Acad Sci USA 92:6991-6995.

Mews M, Meyer M (1993) Modulation of Schwann cell phenotype by TGFbeta 1: inhibition of P0 mRNA expression and downregulation of the low affinity NGF receptor. Glia 8:208-217.

Michailov GV, Sereda MW, Brinkmann BG, Fischer TM, Haug B, Birchmeier C, Role L, Lai C, Schwab MH, Nave KA (2004) Axonal neuregulin-1 regulates myelin sheath thickness. Science 304:700-703.

Morris JK, Lin W, Hauser C, Marchuk Y, Getman D, Lee KF (1999) Rescue of the cardiac defect in ErbB2 mutant mice reveals essential roles of ErbB2 in peripheral nervous system development. Neuron 23:273-283.

Morrissey TK, Levi AD, Nuijens A, Sliwkowski MX, Bunge RP (1995) Axoninduced mitogenesis of human Schwann cells involves heregulin and p185erbB2. Proc Natl Acad Sci USA 92:1431-1435.

Parkinson DB, Dong Z, Bunting H, Whitfield J, Meier C, Marie H, Mirsky R, Jessen KR (2001) Transforming growth factor beta (TGFbeta) mediates Schwann cell death in vitro and in vivo: examination of c-Jun activation, interactions with survival signals, and the relationship of TGF $\beta$-mediated death to Schwann cell differentiation. J Neurosci 21:8572-8585.

Pearson Jr RJ, Carroll SL (2004) ErbB transmembrane tyrosine kinase receptors are expressed by sensory and motor neurons projecting into sciatic nerve. J Histochem Cytochem 52:1299-1311.

Plowman GD, Green JM, Culouscou JM, Carlton GW, Rothwell VM, Buckley S (1993) Heregulin induces tyrosine phosphorylation of HER4/ p180erbB4. Nature 366:473-475.

Rahmatullah M, Schroering A, Rothblum K, Stahl RC, Urban B, Carey DJ (1998) Synergistic regulation of Schwann cell proliferation by heregulin and forskolin. Mol Cell Biol 18:6245-6252.

Ridley AJ, Davis JB, Stroobant P, Land H (1989) Transforming growth factors-beta 1 and beta 2 are mitogens for rat Schwann cells. J Cell Biol 109:3419-3424.

Riethmacher D, Sonnenberg-Riethmacher E, Brinkmann V, Yamaai T, Lewin GR, Birchmeier C (1997) Severe neuropathies in mice with targeted mutations in the ErbB3 receptor. Nature 389:725-730.

Russell KS, Stern DF, Polverini PJ, Bender JR (1999) Neuregulin activation of ErbB receptors in vascular endothelium leads to angiogenesis. Am J Physiol 277:H2205-H2211.
Scherer SS, Salzer J (2001) Axon-Schwann cell interactions in peripheral nerve degeneration and regeneration. In: Glial cell development, Ed 2 (Jessen KR, Richardson WD, eds), pp 299-330. Oxford: Oxford UP.

Shah NM, Marchionni MA, Isaacs I, Stroobant P, Anderson DJ (1994) Glial growth factor restricts mammalian neural crest stem cells to a glial fate. Cell 77:349-360.

Sherman DL, Brophy PJ (2005) Mechanisms of axon ensheathment and myelin growth. Nat Rev Neurosci 6:683-690.

Sliwkowski MX, Schaefer G, Akita RW, Lofgren JA, Fitzpatrick VD, Nuijens A, Fendly BM, Cerione RA, Vandlen RL, Carraway III KL (1994) Coexpression of erbB2 and erbB3 proteins reconstitutes a high affinity receptor for heregulin. J Biol Chem 269:14661-14665.

Sondell M, Fex-Svenningsen A, Kanje M (1997) The insulin-like growth factors I and II stimulate proliferation of different types of Schwann cells. NeuroReport 8:2871-2876.

Suter U, Scherer SS (2003) Disease mechanisms in inherited neuropathies. Nat Rev Neurosci 4:714-726.

Taveggia C, Zanazzi G, Petrylak A, Yano H, Rosenbluth J, Einheber S, Xu X, Esper RM, Loeb JA, Shrager P, Chao MV, Falls DL, Role L, Salzer JL (2005) Neuregulin-1 type III determines the ensheathment fate of axons. Neuron 47:681-694.

Trachtenberg JT, Thompson WJ (1996) Schwann cell apoptosis at developing neuromuscular junctions is regulated by glial growth factor. Nature 379:174-177.

Ullrich A, Coussens L, Hayflick JS, Dull TJ, Gray A, Tam AW, Lee J, Yarden Y, Libermann TA, Schlessinger J, Downward J, Mayes ELV, Whittle N, Waterfield MD, Seeburg PH (1984) Human epidermal growth factor receptor cDNA sequence and aberrant expression of the amplified gene in A431 epidermoid carcinoma cells. Nature 309:418-425.

Vartanian T, Goodearl A, Viehover A, Fischbach G (1997) Axonal neuregulin signals cells of the oligodendrocyte lineage through activation of HER4 and Schwann cells through HER2 and HER3. J Cell Biol 137:211-220.

Vooijs M, Jonkers J, Berns A (2001) A highly efficient ligand-regulated Cre recombinase mouse line shows that LoxP recombination is position dependent. EMBO Rep 2:292-297.

Woldeyesus MT, Britsch S, Riethmacher D, Xu L, Sonnenberg-Riethmacher E, Abou-Rebyeh F, Harvey R, Caroni P, Birchmeier C (1999) Peripheral nervous system defects in erbB2 mutants following genetic rescue of heart development. Genes Dev 13:2538-2548.

Wolpowitz D, Mason TB, Dietrich P, Mendelsohn M, Talmage DA, Role LW (2000) Cysteine-rich domain isoforms of the neuregulin-1 gene are required for maintenance of peripheral synapses. Neuron 25:79-91. 